\title{
THE EFFECT OF THE SURFACE GEOMETRY OF A PHOTOVOLTAIC BATTERY ON ITS EFFICIENCY
}

\author{
Sanjar Shoguchkarov ${ }^{1}$, Isroil Yuldoshev ${ }^{1}$, Elyor Saitov ${ }^{1}$, Alisher Boliev ${ }^{2}$ \\ ${ }^{1}$ Tashkent State Technical University, Department of Alternative energy sources, street Universitet -2, Tashkent, 100095, Uzbekistan \\ ${ }^{2}$ Jizzakh polytechnic institute, Department of energy, street Islam Karimov, Jizzakh, 130100, Uzbekistan
}

\begin{abstract}
Discusses the influence of the shape of the geometric surface of a photovoltaic battery (PVB) on its effectiveness. The features of photovoltaic systems based on silicon modules with different geometric shapes are considered. Expressions are given for determining the seasonal electric power generation of the PVB considering its surface geometry located in the parking lot, as well as calculations, are made to determine the optimal angle of inclination of the PVB to the horizontal surface under the conditions of the city of Tashkent.
\end{abstract}

\section{Introduction}

Nowadays, photovoltaic systems are widely used not only for energy consumption but also are used as architectural elements of urban and rural buildings, for example, sunshades for car parks (Fig 1 a), roofs of individual cottages (Fig 1 b), at the ends of tall buildings (Fig. 1 c), etc.

In this case, photovoltaic batteries not only generate electricity, which can be transmitted to the city network or used to illuminate these objects, but also protect them from solar radiation. Since architectural compositions based on photovoltaic cells have a dual purpose, when designing objects, it is necessary to take into account not only the mechanical and optical characteristics of the new "building material", but also their orientation relative to the solar radiation flux [15]. As a new "building material" used photovoltaic batteries based on mono and polycrystalline silicon, also used flexible photovoltaic batteries.

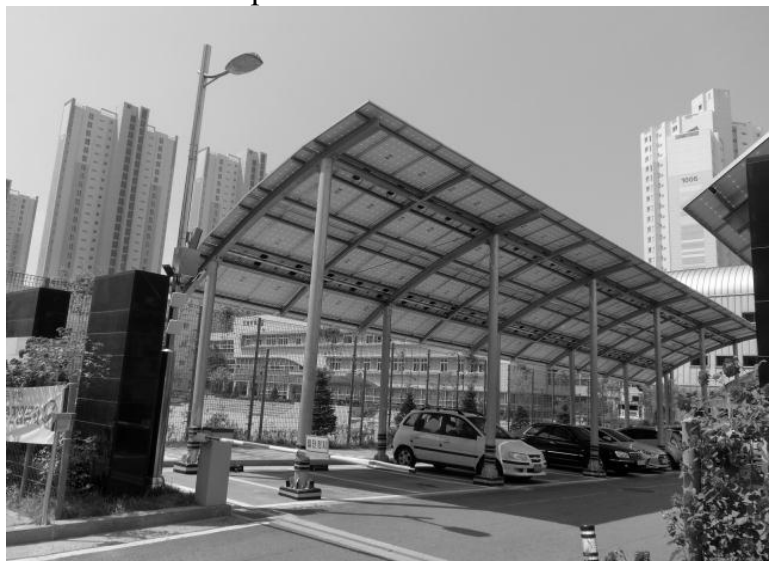

Fig.1. Photovoltaic systems: a) PVB as a car sun protection coating parking in the form of a fragment of a cylindrical surface.

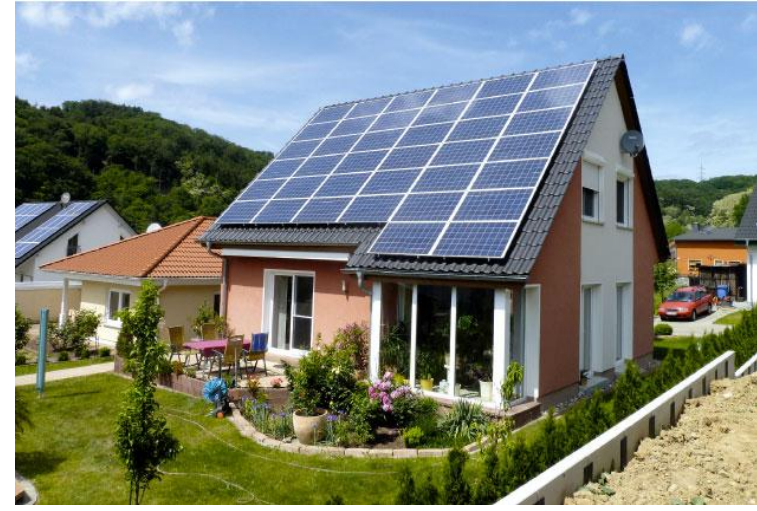

Fig.1. Photovoltaic systems: a) Energy supply of an individual cottage.

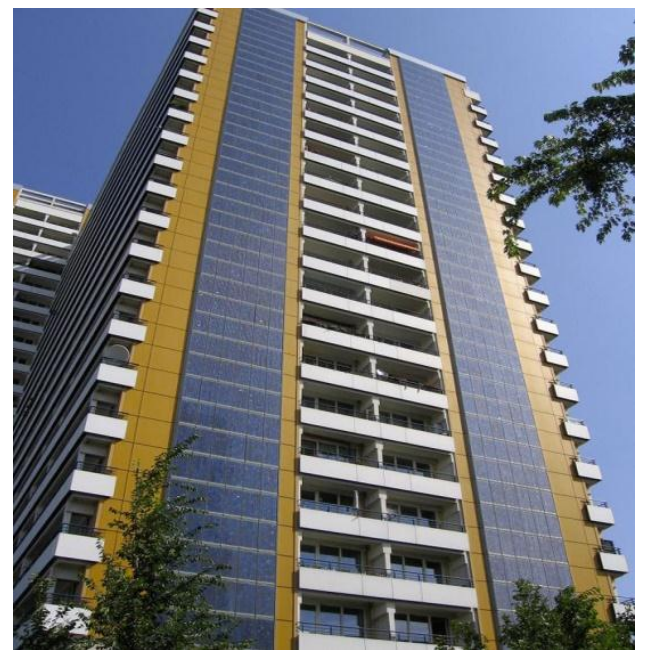

Fig.1. Photovoltaic systems: b) Energy supply of high-rise buildings with a connection to the city network.

The productivity of modern silicon fibs is $16-20 \%$, the exploitation period is 25 years, the power is determined by the number of solar cells and the way they are switched, usually use a photo multiplayer with 
a power. Usually use a PVB with a power of 200 - 300 W.

The performance of flexible PVBs is $\sim 18-24 \%$ (in laboratory conditions), the service life is about $3-5$ years. Unlike silicon PVB, modern flexible solar cells can generate electrical energy in cloudy weather and any time of year. The flexibility of the solar battery allows it to equip the roof with a rough surface, tile roofs, coatings of complex shape [6-14].

\section{Results and discussion}

Let us determine how much electricity production will increase by increasing the area of photoelectric batteries if the silicon PVB in fig. 1 is replaced by a flexible photoelectric battery. The power that is generated by the PVB is determined by the formula $[8,9]$

$$
P=\eta \cdot S \cdot E_{0}
$$

$\eta$ - efficiency of PVB; S- the area of the working surface of PVB; $\mathrm{E}_{0}$ - solar flux density.

Using (2), it is possible to compare the PVB of various types: silicon, thin-film, etc. When increasing the area of the working surface from $S_{1}$ to $S_{2}$, the relative increment of power will be written in the form:

$$
\Delta P=\frac{\eta_{2} S_{2}}{\eta_{1} S_{1}}-1
$$

In order to evaluate the effect of increasing power due to the use of flexible photovoltaic cells, it is necessary to compare the photovoltaic cell with $\eta_{1} \sim$ $\eta_{2}$ or $\eta_{1} / \eta_{2} \sim 1$ :

$$
\Delta P=\frac{S_{2}}{S_{1}}-1
$$

Since the sun cover of a car park is a part of a cylindrical surface (Fig. 1, 2), it is possible to consider the side of a regular polygon inscribed in a circle of radius $\mathrm{R}$ and $L_{1}=6 R \sin \alpha$ as part of the corresponding arc. Inscribed in a circle of radius $\mathrm{R}$, and $L_{2}=A B C D=6 R \alpha$ part of the corresponding arc.

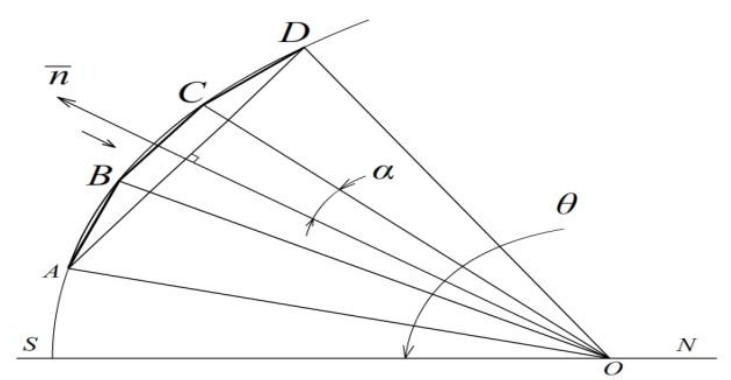

Fig.2. The geometry of the sun cover car parking.
Assuming that the width of each receiving site $\mathrm{AB}=$ $\mathrm{BC}=\mathrm{CD}$ is constant and exceptional and we can write following expression.

$$
\Delta P=\frac{L_{2}}{L_{1}}-1=\frac{6 \alpha R}{6 R \sin \alpha}-1
$$

Finally, (1) will be written as:

$$
\Delta P=\frac{\alpha}{\sin \alpha}-1
$$

if $\mathrm{L}_{1}=1,58 \mathrm{~m}$, and $\mathrm{R}=2 \mathrm{~m}$, then $\alpha \sim 23,0^{\circ}$ and $\Delta \mathrm{P} \sim$ $2,0 \%$. If $\mathrm{R}>\mathrm{L}_{1}$, then $\alpha \sim 0$ and $\Delta \mathrm{P} \sim 0$.

Thus, a change in the geometric shape of the of the PVB area by replacing the standard PVB with a flexible one can be achieved when $\mathrm{L}_{1} \sim \mathrm{R}$.

For the year, the specific production of electric energy of a photovoltaic installation (PVI) is determined by summing up the monthly production values, found in turn, based on the hourly calculation of electric energy production for each average day of the month. The annual generated electric production of the PVI $\left(\mathrm{W}_{0}\right)$ depends on the operating conditions: time of day, location (climatic zone), condition of the PVB working surface, etc [15-17].

$$
W_{o}=P_{0}\left(\sum_{i=1}^{N_{1}} t_{1, i}+\sum_{i=1}^{N_{2}} t_{2, i}+\sum_{i=1}^{N_{3}} t_{3, i}+\sum_{i=1}^{N_{4}} t_{4, i}\right)
$$

where $\mathrm{P}_{0}-$ nominal power PVB by seasons; $\mathrm{N}_{1}, \mathrm{~N}_{2}$ $\mathrm{N}_{3} \mathrm{~N}_{4}$ - respectively, the number of days for the season of the year; $\mathrm{t}_{1}=4 \div 5 \mathrm{~h}, \mathrm{t}_{2}=8 \div 9 \mathrm{~h}, \mathrm{t}_{3}=11 \div 12 \mathrm{~h}, \mathrm{t}_{4}=$ $8 \div 9 \mathrm{~h}$ - daily sunshine by season in Uzbekistan [18]. By the formula (2), the average values of the specific electricity generation of the PVI for a year are calculated.

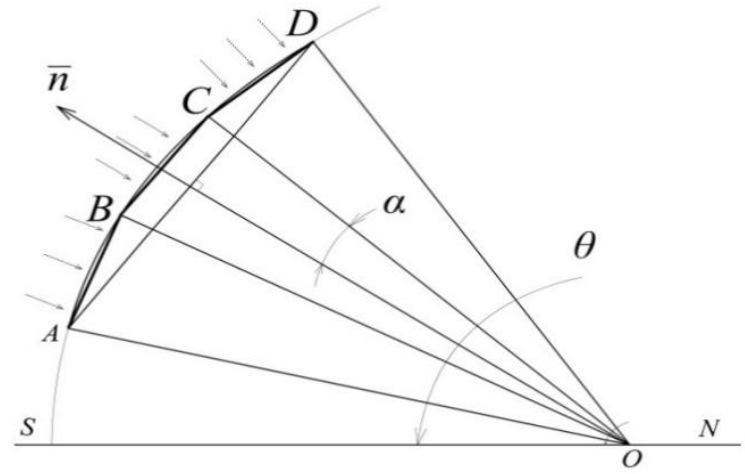

Fig.4. The direction of solar radiation on the PVB located in the parking lot of cars on seasons.

Taking into account the location of the PVB that is described in fig. 4 in the car park during the year and using the expression, you can calculate the seasonal generation of electricity of the PVB:

Angle $\mathrm{AOD}=6 \alpha ; \mathrm{OD}=\mathrm{AO}=\mathrm{R} ; \mathrm{AB}=\mathrm{BC}=\mathrm{CD}=\mathrm{L}_{1}$; $\operatorname{Arc} A B C D=6 R \alpha$ 


$$
\left\{\begin{array}{l}
W_{T .}^{\text {win. }}=\left(\mathrm{P}_{P V B-1}^{\max }+P_{P V B-2}^{\text {aver }}+P_{P V B-3}^{\min }\right) \sum_{i=1}^{N_{1}}\left(t_{1}\right) \\
W_{T .}^{S . A}=\left(\mathrm{P}_{P V B-1}^{a v e r .}+P_{P V B-2}^{\max .}+P_{P V B-3}^{a v e r .}\right) \sum_{i=1}^{N_{2,4}}\left(t_{2,4}\right)(7) \\
W_{T .}^{\text {Sum. }}=\left(\mathrm{P}_{P V B-1}^{\text {min. }}+P_{P V B-2}^{\text {aver. }}+P_{P V B-3}^{\max .}\right) \sum_{i=1}^{N_{3}}\left(t_{3}\right)
\end{array}\right.
$$

Where $P_{P V B}^{\max }, P_{P V B}^{a v e r}$ and $P_{P V B}^{\min }$ - respectively the maximum, average and minimum value of the power of the FEB for the season of the year;

According to expression (7), it can be explained that in winter time the orientation of the receiving site (AB) of the PVB-1 is cost-effective taking into account the height of the Sun above the horizon. The rest of the receiving sites PVB-2 and PVB-3 in terms of the angle of inclination to the horizon has different rated capacities. For the rest of the seasonal period (spring, autumn and summer), PVB-2 (BC) is cost-effective for spring and autumn month while PVB-3 (CD) receive more radiation in summer than other receiving site in terms of solar flux density coming to the perpendicular area.

The PVB should be located in the most lighted place and should be installed in a southerly direction. It is also worth remembering about the seasonal changes in the angle of the Sun, under which the solar radiation of the receiving area of the installation falls. For each latitude, it has its own optimum angle of the flat inclination of the PVB installation and only for the areas near the equator the PVB should be horizontal.

It is usually recommended to change the angle of inclination of the PVB three times a year to the fixing positions in the supporting structure (Fig.3). If the PVB installation is installed on a flat surface, for example, a soft roof, it is extremely important for the PVB to be raised above its surface. That is, there should be space under the equipment for free air circulation. The distance between the plane and the PVB should be more than $\geq 10 \mathrm{~cm}$, and otherwise, the PVB will be very hot, which leads to a decrease in the generation of electricity in the battery.

The PVB support structure must be resistant to adverse environmental factors: strong wind gusts, large amounts of precipitation and corrosive properties.

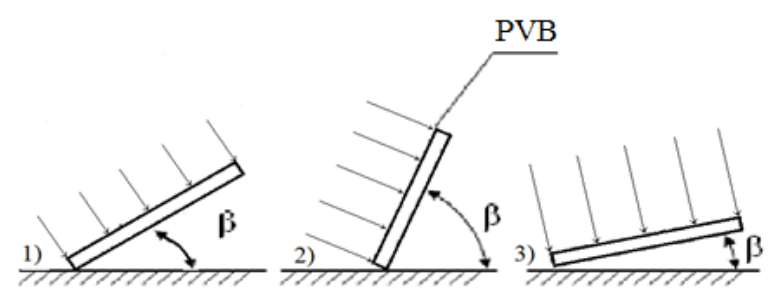

Fig.3. Determination of tilt angle of PVB for spring and autumn equinoxes (1), for the winter period (2) and for the summer period (3)

The receiving area of the PVB is oriented daily by the angle of inclination, which is determined by the formulas:

$$
\beta^{0}=\varphi^{0}-\delta^{0}
$$

where $\varphi^{0}$ - is the northern latitude of the terrain; $\delta^{0}$ the declination angle of the Sun for a given day [19].

The declination of the Sun on a given day is determined by the Cooper formula:

$$
\delta=23,45 \sin \left(360 \frac{284+n}{365}\right)
$$

where $\mathrm{n}$ is the ordinal number of the day of the year, counted from January 1 . The number of the average settlement day of the month for I-XII months of the year is usually taken as in [20].

The optimal monthly angles of the tilt of the PVB for the city of Tashkent found according to expression (8), are given in Fig.5. Respectively the coordinates in geographical degrees of the city of Tashkent is $\varphi^{0}$ $41,26465^{\circ}$ and $\psi^{0}-69,21627^{0}$.

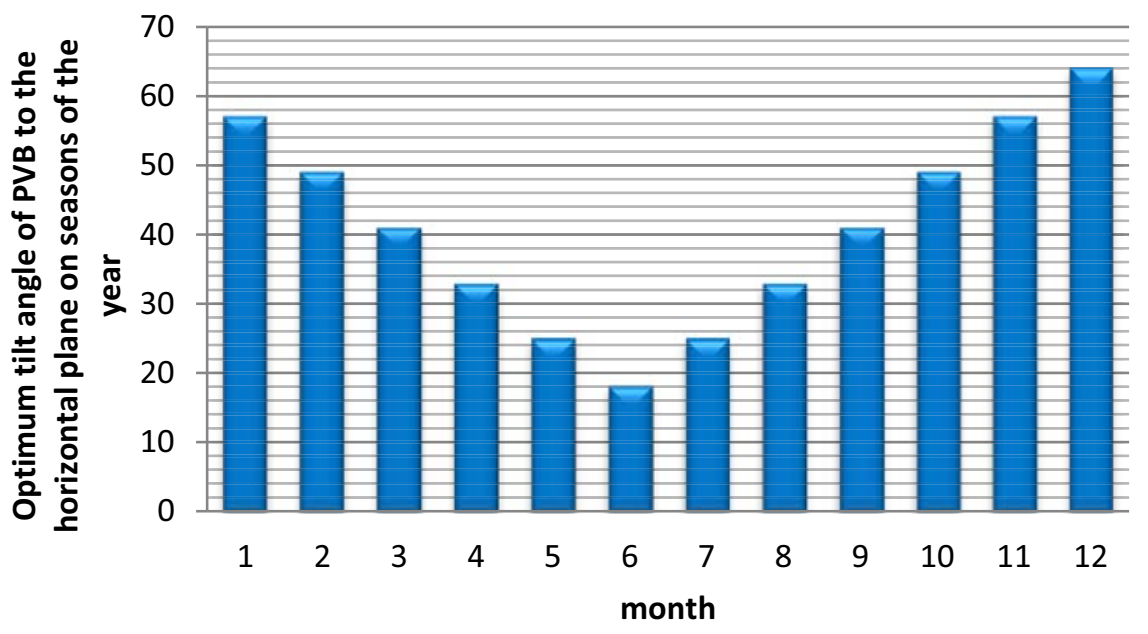

Fig.5. The optimal monthly angles of tilt of the PVB for the city of Tashkent 
The calculation shows that for the spring and autumn equinox the optimal angle of inclination is equal to the latitude of the region. However, during the operation of the PVB, a change in the orientation of the angle of inclination by months creates difficulties. Thus, the choice of the angle of inclination of the PVB is carried out in seasonal variations (in winter, spring, autumn and summer).

Knowing insolation in a given geographical location, we find that the minimum energy of solar radiation is characteristic for January and December. In these two months, the declination of the Sun ranges from $-17,5^{0}$ to $-23,5^{0}$. The average value of the declination angle is determined through the arithmetic average cosines of these angles:

$$
\cos \delta_{\text {aver. }}=\frac{\cos \left(-17,5^{\circ}\right)+\cos \left(-23,5^{\circ}\right)}{2}
$$

From where $\delta_{\text {aver }}=-20,7^{0}$. Then the optimal angle of inclination for the winter period of Tashkent.

$$
\beta^{0}=41,3^{0}-\left(-20,7^{0}\right)=62,0^{0}
$$

Calculations will continue for the summer period (June and July):

$$
\cos \delta_{\text {aver. }}=\frac{\cos \left(23,5^{\circ}\right)+\cos \left(18,5^{\circ}\right)}{2}
$$

From where $\delta_{\text {aver }}=21,1^{0}$. The optimum angle of inclination for the summer period;

$$
\beta^{0}=41,3^{0}-21,1^{0}=20,2^{0}
$$

Below is the location of the PVB in the angle of inclination to the horizontal plane of the seasons of the year in the conditions of the city of Tashkent.

table 1

The optimum tilt angle of PVB to the horizontal plane on seasons of the year

\begin{tabular}{|c|c|c|}
\hline Winter & $\begin{array}{c}\text { Spring and } \\
\text { autumn }\end{array}$ & Summer \\
\hline$\sim 62^{0}$ & $\sim 41^{0}$ & $\sim 20^{0}$ \\
\hline
\end{tabular}

\section{Conclusion}

The orientation of the PVB on the angle of inclination leads to two positive effects:

- an increase in the power of the PVB due to incident solar radiation perpendicular to the front surface of the module;

- a significant reduction in battery charging time due to an increase in battery charging current with an increase in PVB power.

In connection with the foregoing, solar power plants with a certain curvature of the plane of solar panels do not require seasonal variations in the angle relative to the horizontal plane of the photovoltaic systems. In addition, solar power plants with a certain curvature of the plane in solar panels, cleaning their surface is easier in rainy weather conditions and it is possible to clean their surface with jet water.

\section{References}

1. Soteris A. Kalogirou "Building integration of solar renewable energy systems towards zero or nearly zero energy buildings" International Journal of LowCarbon Technologies, Vol.10, Issue 4, pp. 379-385, 2015.

2. Azhar Ghazali, Elias Ilias Salleh, Lim Chin Haw, Sohif Mat, Kamaruzzaman Sopian "Feasibility of vertical photovoltaic system on high-rise building in Malaysia: performance evaluation" International Journal of Low-Carbon Technologies, Vol. 12, Issue 3, pp. 263-271, 2017.

3. Benedicto Joseph, Tatiana Pogrebnaya and Baraka Kichonge "Review on Energy Performance, Challenges and Future Potential" Academic Editor: Wing-Kei Ho Published 20 Oct. 2019

4. Emrah Biyika, Yusuf Baver Atlıf "A key review of building integrated photovoltaic (BIPV) systems" Engineering Science and Technology, an International Journal Volume 20, Issue 3, June 2017, Pages 833-858 5. A Allouhi, R Saadani, T Kousksou, R Saidur, A Jamil, M Rahmoune "Grid-connected PV systems installed on institutional buildings: Technology comparison, energy analysis and economic performance" Energy and Buildings, pp.188-201, 2016. 6. I. Candan, M. Parlak, Ç. Erçelebi "PbS quantum dot enhanced p-CIGS/n-Si heterojunction diode" Journal of Materials Science: Materials in Electronics. November.2018

7. Q. Tai, K. Tang, F. Yan "Recent progress of inorganic perovskite solar cells" Energy and Environmental Science. 2019

8. A. L. Fahrenbruch, R. H. Bube Fundamentals of Solar Cells: Photovoltaic Solar Energy Conversion (New York: Academic Press, 1983); Translation into Russian lang A. Farenbruch, R. Byub Solar Elements: Theory and Experiment, Trans. from the English. - M.: Energy-Atomizdat, pp - 280. 1987.

9. V.G. Dyskin, M.N. Tursunov, I.A. Yuldoshev "Ustroystvo dlya opredeleniya optimal'nykh uglov oriyentatsii fotoelektricheskikh batarey" Problemy energo-resursosberezheniya. Tashkent, №3-4, str. 7982. 2013.

10. M. N. Tursunov, R. A. Muminov, V. G. Dyskin, I. A. Yuldoshev. "A mobile photothermal converter and its operating characteristics" Applied Solar Energy January Vol. 49, Issue 1, pp. 16-18. 2013.

11. I.A. Yuldoshev, Kh.K. Tashmatov, E.B. Saitov, B. Wurl' "Vvod i ekspluatatsiya solnechnoy fotoelektricheskoy stantsii, integrirovannoy s lokal'noy elektricheskoy set'yu" Geliotekhnika, № 4. str. 59-62, 2017.

12. M.N. Tursunov, KH. Sabirov, I.A. Yuldoshev i dr. "Fotoelektricheskaya ustanovka" Patent na poleznuyu model' №FAP 01195, ot 15.03.2017.

13. K. Chopra, S. Das Tonkoplenochnyye solnechnyye elementy M.: Mir.1986. str.-435 
14. V.P.Afanas'yev, Ye.Terukov, A.A. Sherchenko "Tonkoplenochnyye solnechnyye element" Izdatel'stvo SPbGETU “LETI”. 2011. S. -1689.

15. M. N. Tursunov, V.G. Dyskin, I.A Yuldashev, Kh. Sobirov, Park Jeong Hwoan. "A Criterion of Contamination of the Glass Surface of Photovoltaic Batteries" Applied Solar Energy. V.51. pp. 163-164, 2015.

16. M.N. Tursunov, R. A. Muminov, O. F. Tukfatullin, I. A. Yuldoshev, and E.T. Abdullaev Photothermal Electric Battery Based on Silicon Solar Cells Applied Solar Energy, Vol.47, No.1, pp. 63-65, 2011/

17. M.N. Tursunov, I.A. Yuldoshev "Razrabotka fotoelektricheskikh batarey i ustanovok, effektivno rabotayushchikh v usloviyakh Tsentral'noy Azii" Problemy energo-resursosberezheniya, Tashkent, Spetsial'nyy vypusk, str. 160-165, 2011.
18. I.A. Yuldoshev "Otsenka texniko-ekonomicheskix pokazateley kombinirovannix fotoelektricheskix ustanovok" Ekonomika i innovatsionniy texnologii, №2, mart, aprel, str.1-6, 2016

19. P.B. Tixonov "Obosnavanie parametrov fotoelektricheskogo teplovogo modulya" Disertatsiya na soiskanie uchenoe stepen kandidata texnicheskiy nauk. Vserossiyskiy nauchno-issledovatiskiy institut elektrifikatsii seleskogo xozaystva (VIESX). 2014. Str. 17

20. N.V. Kharchenko "Individual solar installations" M.: Energoatomizdat, 127-str. 1991. 